\title{
Bank Capitalisation and Stock Market Liquidity: Assessing the Evidence
}

\author{
Alaa M. Soliman*, Joseph Obi \\ Leeds Business School, Leeds Beckett University, Leeds, England \\ Email: *a.soliman@leedsbeckett.ac.uk
}

How to cite this paper: Soliman, A.M. and Obi, J. (2017) Bank Capitalisation and Stock Market Liquidity: Assessing the Evidence. Theoretical Economics Letters, 7, 1747-1760.

https://doi.org/10.4236/tel.2017.76118

Received: May 30, 2017

Accepted: October 15, 2017

Published: October 18, 2017

Copyright ( 2017 by authors and Scientific Research Publishing Inc. This work is licensed under the Creative Commons Attribution International License (CC BY 4.0).

http://creativecommons.org/licenses/by/4.0/

\section{cc) (i) Open Access}

\begin{abstract}
This paper provides both theoretical and empirical evidence for assessing the relationship between bank capitalisation and stock market liquidity. It estimates a bivariate VAR-GARCH (1.1) model to examine the linkage between bank capitalisation and stock market liquidity in Nigeria using annual data covering the period from 1986 to 2014. The findings of this paper show that bank capitalisation enables banks to give out more loans to the public and this increase in lending has a positive impact on stock market liquidity growth The findings support the view that capitalised banks are well equipped to absorb and diversify risk, give out more loans, improve liquidity in the economy and improve stock market performance.
\end{abstract}

\section{Keywords}

Bank Capitalisation, Stock Market, Nigeria, VAR

\section{Introduction}

Stock markets play a major role in financial intermediation in both developed and developing countries by channelling idle funds from surplus to deficit units in the economy (Abiodun and Okunola [1]. Al-Faki [2] views the stock market as an aspect of the financial market comprising a network of specialised financial institutions, series of mechanisms, processes and infrastructure that in various ways facilitate the bringing together of suppliers and users of medium to long term capital for investment in socio-economic development projects. These markets channel the wealth of savers to those who can put it to long term investment. The stock market helps in channelling capital or long term resources to firms with relatively high and increasing productivity (Sullivan and Sheffrin, [3]). 
Globally, the state of the stock market gives an indication of the state of health of a nation's economy as it measures the stability of the nation's economy to the extent to which economic growth can rely on it (Nigerian Stock Exchange Fact Book, [4]). Usman [5] is of the opinion that the stock market plays an important role in the economic growth of a nation, while Nwude [6] argues that it is unarguable that the stock market has a role to play in any economy. Kolapo and Adaramola [7] observe that the performance of the stock market is an impetus for economic growth and development. Stock market also encourages the inflow of foreign capital when foreign companies or investors invest in domestic securities and provide the needed seed money for creative capital development and acts as a reliable medium for broadening the ownership base of family owned and dominated companies. The importance of the stock market in the economic growth and development of a nation underscores the significance of research to determine some of the determinants of stock market growth.

Traditionally, banks and stock markets are often viewed as competing sources of financing (Allen and Gale, [8]; Boot and Thakor, [9]; Song and Thakor, [10]). This banks versus markets distinction implies that each sector (banks or markets) develops at the expense of the other, and hence, regulators have tried to strike a balance between the two (Song and Thakor, [10]). In a significant shift from this dominant view that the primary form of interaction between the two intermediaries is that they compete, Song and Thakor [10] suggest that banks and markets exhibit three forms of interactions: they compete; they complement each other; and they co-evolve. This study aligns with the complementary and co-evolving relationship of the two financial intermediaries to show that the increase in bank capital leads to stock market growth. This study is of the view that strong banking institutions are necessary for the growth of the stock markets and well-functioning stock markets are essential for the banks to be sufficiently capitalised to perform their intermediation roles with minimum risk. The recent waves of bank capitalisations, mergers and consolidations in Nigeria and globally, have significantly increased the banks' equity ratio and reduced the chances of distress in the banking system (Clementina and Isu, [11]). An important question that will be relevant to policy makers is to find out the implications of the banking sector capitalisation on the stock market growth. The answer to the question largely depends upon the ability of the capitalisation to transmit to improved liquidity in the stock market since liquidity has been identified in a large body of literature as the main channel for stock market growth.

Previous research focused on either the macroeconomic approach or the institutional approach. Previously identified macroeconomic variables which impact on stock market growth include Income level, Gross domestic investment and Banking and financial sector development. To the best of our knowledge, no previous studies examined the influence of bank capitalisation on stock market growth, and none, specifically examined that relationship in an emerging economy such as Nigeria. 
This research paper examines the impact of bank capitalisation (i.e. increase in the ratio of banks' equity to total assets) on stock market growth using data from Nigeria. The objective of this study is to answer the questions concerning the impact of increasing banks' capital on stock market performance and the transmission channels of bank capitalisation to stock market growth.

The remainder of this paper is structured as follows. Section two includes a review of related literature on bank capitalisation and stock market growth. Section three outlines the theoretical modelling approach. Section four explores the methodology and data used and reviews estimation results. Section five offers concluding remarks.

\section{Determinants of Stock Market Growth}

Stock market development has attracted great attention as a source of economic expansion. The initial evidences were reported by Gurley and Shaw [12], Goldsmith [13], McKinnon [14], Shaw [15] and Caporale et al. [16] [17] while a pioneering empirical study on the causes of stock market growth was done by Calledron-Rossell [18] who find that stock market development is a combined effect of economic growth and liquidity on both stock prices and number of listings. An advanced study about the association among stock market growth and financial intermediation in developing countries was done by Demirguc-Kunt and Levine [19]. The outcome of their work indicate that most stock market growth signs are highly associated with banking sector development signs but their work did not investigate specific banking sector growth signs. Different from macroeconomic variables, La porta et al. [20] attribute stock market growth to common law and other legal rules covering protection of corporate shareholders and creditors. They were of the opinion that quality and enforcement of laws including disclosure rules, investor protection, shareholder rights and anti-director rights are important determinants of stock market growth.

Further evidence was provided by Garcia and Liu [21]. They find that stock markets and intermediary financial institutions (banks) go hand in hand rather than replacing one another in the growth process. Their study adopts the macroeconomic approach to test stock market growth because accurate information on institutional variables is limited in many developing countries, more so, institutional factors are directly reflected in macroeconomic factors, for instance, legal rule is highly correlated with stock market liquidity (Demirguc-Kunt and Levine, [19]). Yartey [22] in a study of the stock market growth determinants in Africa, identifies both institutional and macroeconomic factors as important variables. They include financial, economic and institutional variables such as banking sector development, political risk, private capital flows and remittances in his analysis. Our study differs from Yartey's [22] in that it uses country specific data set. The cross country data set used by Yartey [22] does not recognise that the determinants of stock market growth vary from country to another depending on the nature of regulatory, economic and institutional structures in 
place in each country. In a related study, Billmeier and Massa [23] observe that stock market growth is an integral part of financial development which is in turn associated with economic growth. They note that study of stock markets and what contributes to its growth has received a great deal of attention because it has been identified as a source of financial development and ultimately, economic growth. Their study focus on the effect of hydrocarbon wealth (oil wealth) and remittances on stock market growth noting that the impact of resource endowment has mainly been investigated in the context of economic growth in general and not so much with regards to stock market growth. Unlike Sachs and Warner [24], they find that both institutions and remittances have positive and significant impact on market capitalisation especially in countries with significant hydrocarbon endowment. In countries with natural resource endowment especially significant hydrocarbon deposit, oil price boom was seen to be a major driver of stock market capitalisation. Earlier in a similar study, Sachs and Warner [24] find a negative relationship between natural resource endowment and stock market growth. They cited a number of historical cases including rent seeking, slow industrial growth due to real exchange rate appreciation, increased volatility of commodity prices and weakened institutional quality because government has less incentive to promote industrial growth, given the advantage they draw from resource rent.

A more recent study by Cherif and Gazder [25] used both panel data and instrumental variables techniques for 14 MENA countries over the period of 1990 to 2007 to examine the influence of macroeconomic environment and institutional quality on stock market growth. Their findings indicate that stock market growth is influenced by income level, stock market liquidity, savings rate and interest rate. They show that banking and stock market sectors are complementary instead of being substitutes. In addition, they find that the institutional environment does not appear to be a driving force for the stock market growth in the region. However, their study uses cross country panel data which has been criticised as not being capable of isolating country specific conditions such as nature of regulatory mechanisms, economic policies as well as institutional structures (Kemobi and Tarus, [25]). In their study, Kemobi and Tarus [25] investigated the macroeconomic factors that cause stock market development in Kenya for the period between 2000 and 2009 using Error Correction Models (ECM) and Johansen and Jusilus co-integration technique on quarterly data. Their results confirm that stock market liquidity and banking sector development are important determinants of the growth of the Nairobi stock market. Their study also shows that stock market stability is not a significant forecaster of the development of the stock market. Kemobi and Tarus [25] study is similar to our study in the use of country specific data because the determinants of stock market growth vary from country to another in the use of secondary data which is less prone to bias and in adopting and modifying the Calledron-Rossell model. However, their model did not incorporate bank capitalisation variable in the re- 
gression. Idowu and Babatunde, [26] studied the effect of financial reforms on capital market development in Nigeria, using the Ordinary Least Squares regression technique and found that financial reforms impact significantly on capital market growth but Central bank variables and other financial institution interacted negatively with market capitalisation in Nigeria. Similar to this study, they used the Calledron-Rossell theoretical foundation, and single country time series secondary data, but their model differs from this study in using market capitalisation to measure stock market growth and for not including bank capitalisation as a main determining factor in the stock market growth process.

Al-Mamun [27] studied the effect of macroeconomic and market specific dynamics on stock market development in global growth generating countries and observes that empirical questions addressing the determinants of stock market growth has been considerably low. He used panel ARDL technique and finds that foreign direct investment, real interest rates, and stock market operating characteristics influence stock market growth in the countries under study. Ita and Duke [28] argue that stock markets provide channels for the mobilisation and allocation of funds in the economy and view stock market growth to be a function of size, liquidity, volatility, concentration and integration with the world market. They used co-integration and error correction models on secondary data to analyse the degree of the effect of each of the independent variables on stock market growth. Their variables include GDP, financial sector development represented by $\mathrm{M}_{2} / \mathrm{GDP}$, market liquidity, inflation rate, domestic savings and investment and gross fixed capital formation but the model has not included bank capitalisation. In a study of the macroeconomic determinants of stock market development in Jordan, El-Nader and Alraimony [29] used monthly data between 1990 and 2011 and applied VECM and variance decomposition to demonstrate that money supply, value traded, consumer price index and credit to the private sector have positive and considerable influence on stock market growth while GDP and remittances have negative impact on stock market growth in Jordan. Although their study used secondary data and variance decomposition method similar to this study, it has not included bank capital variable in the analysis.

Empirical literature show that previous studies focus on either the macroeconomic approach or the institutional approach. Most of the identified macroeconomic variables that impact on stock market growth includes income level, gross domestic investment, banking and financial sector development, stock market liquidity, private capital flows, savings and investment and macroeconomic stability policies like inflation rates, interest rates and exchange rates (Ita and Duke, [28] and Yartey, [22]). The institutional variables include law and order, enforcement of legal rules, anti-director rights, shareholders' protection rights, bureaucratic processes, democratic accountability and corruption (La-porta et al. [20]). None of those studies has examined the influence of bank capitalisation on stock market growth. 
This study, instead, considers bank capital as the main determinant of stock market growth through liquidity channel. It further modifies the Calderon-Rossell model by using single-country time series data instead of panel data and by using stock market liquidity instead of market capitalisation as the measure of stock market growth.

\section{The Theoretical Model of Bank Capitalisation and Stock Market Growth}

Various previous studies [e.g. Berger and Bouwman [30] and Yartely [22] acknowledged that well capitalised banks increase lending. This is very well illustrated in the risk absorption hypothesis by Berger and Bouwman [30]. Increase in lending increases the liquidity of the stock market operators (i.e. hedge funds, investors and brokers). Increase in liquidity of stock market operators leads to more trading in the stock market and thus, increases stock market turnover which is a measure of liquidity. Stock market liquidity has been recorded in literature as a major contributing factor to stock market growth (Yartey, [22]).

Previous Studies on the relationship between financial development and economic growth including stock market growth stopped short of recognising bank capitalisation as one of the contributors to better performing stock market. The inclusion of bank capitalisation in stock market growth determinants is the novelty in this study. Our argument is that capitalised banks are well equipped to absorb and diversify risk, give out more loans, improve liquidity in the economy and improve stock market performance. This is the theoretical proposition which is tested empirically in this study. All the previous studies on stock market growth have not acknowledged the importance of risk management using bank capital. The channel by which bank capitalisation affect stock market growth through risk absorption and increase in lending has been overlooked in previous studies.

Our model modifies both the Calderon-Rossell [18] and Berger and Bouwman [30] models by introducing bank capital as the main determinant of stock market growth through liquidity in the stock market. It further modifies the Calderon-Rossell model by using single country time series data instead of a panel and by using stock market liquidity instead of market capitalisation as the measure of stock market growth. Well capitalised banks increase the banks' safety nets and give them higher capacity to absorb risk and create more loans to traders and investors. The increase in loans enables investors and traders to increase their participation in the stock market in two ways. First, investors have more liquidity to subscribe to primary market offers and in the process, increasing the subscription rate and success of Initial Public Offerings (IPOs). In addition, the increased subscription in the primary markets creates more shareholders and enhances market efficiency. Secondly, the increase in loans to traders boosts their liquidity which empowers them to participate more in the secondary market. The Increase in secondary market participation will lead to a larger 
number of transactions and more units of stock and shares exchanged in the secondary markets. The relationship can be summarised as follows;

$$
\begin{aligned}
\text { Stock market liquidity } & =f(\text { investors and traders' liquidity }) \\
& =f(\text { well capitalized banks })
\end{aligned}
$$

The model also recognises macroeconomic variables, macroeconomic stability and institutional variables as contributing factors to stock market growth. The assumptions prior to the modelling process includes the risk absorption hypothesis as presented by Berger and Bouwman [30] and a linear dependence of stock market liquidity on the rate of change of bank capital. Next, a differential equation for the relationship, including a mathematical model that incorporates the variables already mentioned is formulated.

We first assume that the rate of change in stock market liquidity is proportional to the rate of change in bank capital and other variables that affect stock market growth.

$$
\frac{\mathrm{d} l}{\mathrm{~d} t}=\frac{\mathrm{d} B G}{\mathrm{~d} i}
$$

Equation (1) basically summarises the idea that the rate of change in stock market liquidity is proportional to the rate of change in bank capital plus other variables that affect stock market growth. If the various components of $G$ are identified, Equation (1) can be rewritten as.

$$
\frac{\mathrm{d} l}{\mathrm{~d} t}=\frac{\mathrm{d} B}{\mathrm{~d} t}+\frac{\mathrm{d} M}{\mathrm{~d} t}+\frac{\mathrm{d} S}{\mathrm{~d} t}
$$

Equation (2) summarises the idea that the rate of change in stock market liquidity is directly proportional to the rate of change in bank capital, macroeconomic variables, macroeconomic stability and institutional variables.

We solve the above differential relationship by integrating both sides of Equation (2) and we get.

$$
\begin{gathered}
\int \mathrm{d} L=\int B(t)+M(t)+S(t) \\
L=K \int B(t) \mathrm{d} t+K \int M(t) \mathrm{d} t+K \int S(t) \mathrm{d} t
\end{gathered}
$$

We model the impact of bank capital on stock market growth by stating that

$$
L(t)=B(t)+M(t)+S(t)+I(t)
$$

where

$$
\begin{aligned}
& B(t)=B(0)+P(t)+N(t) \\
& S(t)=S_{1}+S_{2}+S_{3}+\cdots+S_{n}
\end{aligned}
$$

Subscripts 1,2 , and 3 are the different variables and $n$, represents the number of variables in each group. By introducing the error term, Equation (5) can be written as

$$
L(t)=B(t)+M(t)+S(t)+\mu(t)
$$

where $\mu(t)$ is the error term. 
Equation (8) can be reduced to a simple regression model by replacing the dependent variable with $Y$ and the independent variables with $x_{1}, x_{2}, x_{3}$ respectively, while introducing $b_{0}, b_{1}, b_{2}, b_{3}$ as regression coefficients as follows,

$$
Y=b_{0}+b_{1} x_{1}+b_{2} x_{2}+b_{3} x_{3}+\mu
$$

where $Y$ is the stock market liquidity growth, $x_{1}$ is bank capital and growth, $x_{2}$ is macroeconomic variable and $x_{3}$ is macroeconomic stability variables.

Equation (9) can be written explicitly as

$$
L(t)=b_{0}+b_{1} B(t)+b_{2} M(t)+b_{3} S(t)+\mu(t)
$$

Equation (10) shows that stock market liquidity growth is the result of bank capitalisation plus the combined effects of macroeconomic variables, macroeconomic stability and institutional variables.

There are conflicting theoretical arguments about institutional determinants of stock market growth. While some researchers acknowledge their impact, others dismiss them as not having significant impact. To make this model all inclusive, this model would have recognised them because institutional political variables like political risk, corruption, rule of law, and bureaucratic stability have some influence especially, in developing countries. However, data for institutional variables were limited to only ten years out of thirty four years' time span for the study. Because of insufficient data to make a meaningful analysis, institutional variables are excluded from the model. However, as was reported in both Garcia and Liu [21] and Demirguc-Kunt and Levine [19], institutional factors are directly reflected in macroeconomic factors, for instance, legal rule is highly correlated with stock market liquidity. For the above reason, the exclusion of institutional variables will not significantly alter the result of the regression.

\section{The Model}

We model the stock market turnover ratio as proxy for stock market liquidity and bank capitalisation in Nigeria using a bivariate VAR-GARCH $(1,1)$ specification. The study hypothesises that bank capitalisation enables banks to give out more loans to the public and this increase in lending has a positive impact on stock market liquidity growth. The model has the following specification:

$$
x_{t}=\alpha+\beta x_{t-1}+\gamma z_{t-1}+u_{t}
$$

where $x_{t}$ is growth and capitalisation and $z_{t-1}$ is exogenous shocks measured by US stock market turnover and economic growth. The residual vector $u_{t}=\left(\varepsilon_{1, t}, \varepsilon_{2, t}\right)$ is bivariate and normally distributed $u_{t /} y_{t-1} \sim\left(0, H_{t}\right)$ with its conditional variance covariance matrix given by

\section{Methodology and Analysis}

The annual time series covered is 34 years, from 1981 to 2014, representing the most significant period of banking sector development in Nigeria. The 1980's witnessed the beginning of financial liberalisation and a series of bank capitalisa- 
tions in Nigeria, while year 2004 saw a major milestone in capitalisation in the country. The period was chosen to enable the researcher investigate the development in the stock market variables both pre and post the various capitalisation exercises. The data source for stock market liquidity the Nigerian Stock Exchange (NSE), and for bank capitalisation is the Central Bank of Nigeria. The data were converted into ratio scale of measure by using their natural log forms or by dividing with other data (i.e. GDP). The statistical model includes stock market turnover as a proxy for market liquidity and bank capitalisation measured by the ratio of aggregate commercial banks' equity to total assets.

The estimated VAR-GARCH $(1,1)$ models with the associated robust standard errors and likelihood function values are presented in Table 1 . We select the optimal lag length of the mean equation using both Akaike information criterion (AIC) and the Schwarz information criterion (SIC). In case of contradicting results between AIC and SIC, we tend to use AIC results as suggested by

Table 1. Estimated VAR-GARCH $(1,1)$ model.

\begin{tabular}{|c|c|c|c|c|c|}
\hline & Coefficient & S.E. & & Coefficient & S.E. \\
\hline \multicolumn{6}{|c|}{ Conditional Mean Equation } \\
\hline$\alpha_{1}$ & 0.0023 & $(0.0014)$ & $\beta_{11}$ & 0.652 & $(0.0072)$ \\
\hline$\alpha_{2}$ & 0.0072 & $(0.0125)$ & $\beta_{22}$ & 0.842 & $(0.0182)$ \\
\hline$\gamma_{11}$ & -0.0042 & $(0.0018)$ & $\beta_{12}$ & & \\
\hline$\gamma_{22}$ & -0.0032 & $(0.0012)$ & $\beta_{12}^{*}$ & & \\
\hline$\eta_{11}$ & 0.0236 & $(0.0034)$ & $\beta_{21}$ & 0.0562 & $(-0.031)$ \\
\hline$\eta_{22}$ & 0.0261 & $(0.2931)$ & $\beta_{21}^{*}$ & 0.0135 & $(0.0021)$ \\
\hline \multicolumn{6}{|c|}{ Conditional Variance Equation } \\
\hline$c_{11}$ & 0.0062 & $(0.0027)$ & & & \\
\hline$c_{12}$ & 0.0712 & $(0.01660$ & & & \\
\hline$s_{11}$ & 0.28671 & $(0.00120$ & $\alpha_{11}$ & 0.0127 & $(0.0921)$ \\
\hline$s_{21}$ & & & $\alpha_{21}$ & & \\
\hline$s_{21}^{*}$ & & & $\alpha_{21}^{*}$ & & \\
\hline$s_{12}$ & 0.0821 & $(0.0112)$ & $\alpha_{12}$ & 0.5521 & $(0.0012)$ \\
\hline$s_{12}^{*}$ & 0.0021 & $(0.0821)$ & $\alpha_{12}^{*}$ & 0.3281 & $(-0.0231)$ \\
\hline$S_{22}$ & -0.8321 & $(0.0023)$ & $\alpha_{22}$ & -0.8123 & $(0.0082)$ \\
\hline \multicolumn{6}{|c|}{ Log Lik 11234.21} \\
\hline & alisation (3) & 3.2912 & \multicolumn{2}{|c|}{ LBS Growth (3) 8.0152} & \\
\hline & alisation (3) & 6.1273 & \multicolumn{2}{|c|}{ LBS $^{2}$ Growth (3) 6.9172} & \\
\hline
\end{tabular}

Note: Standard errors (S.E.) are calculated using the quasi-maximum likelihood method of Bollerslev and Wooldridge [33]. LBS Capitalisation (3) and $\mathrm{LBS}^{2}$ capitalisation are respectively the Ljung-Box test [37] of significance of autocorrelations of three lags in the standardized and standardized squared residuals for bank capitalisation and stock market growth. Parameters $\beta_{21}, \alpha_{12}$ and $s_{21}$ measure the causality effect running from bank capitalisation to stock market growth 
Stock [31]. The parameter estimates for the conditional means indicate statistically significant bidirectional spillovers-in-mean at the standard 5 percent level of significance. Specifically, spillovers from bank capitalisation are significant than from stock market growth $\left(\beta_{12}<\beta_{21}\right)$.

Concerning the conditional variance equations, the estimated "own-market" coefficients are statistically significant and the estimates of $s_{11}$ show a high degree of volatility of turnover.

By means of Wald tests we test several other hypotheses, specifically (i) the presence of spillovers from stock market turnover volatility $\left(\alpha_{21}=s_{21}=0\right)$ to bank capitalisation volatility; (ii) the presence of spillovers from bank capitalisation volatility $\left(\alpha_{12}=s_{12}=0\right)$ ) to stock market turnover volatility. The findings reported in Table 1 suggest the following.

$$
C_{t}=\left[\begin{array}{ll}
c_{11 t} & c_{12 t} \\
c_{12 t} & c_{22 t}
\end{array}\right]
$$

The parameter vector of the mean turnover equation 1 is given by constant $\alpha=\left(\alpha_{1}, \alpha_{2}\right)$, the autoregressive term $\beta=\left(\beta_{11}, \beta_{12}+\beta_{12}^{*} / \beta_{21}+\beta_{21}^{*}, \beta_{22}\right)$, monetary policy shocks $\gamma=\left(\gamma_{11} / \gamma_{22}\right)$ and other exogenous parameters $\eta=\left(\eta_{11} / \eta_{22}\right)$. The parameter matrices for the variance equation 2 are defined as $f_{0}$ and one unrestricted matrix $S_{11}$. The second moment will take the following form:

$$
\begin{aligned}
C_{t}= & f_{0}^{\prime} f_{0}+\left[\begin{array}{cc}
s_{11} & s_{12}+s_{12}^{*} \\
s_{21}+c_{21}^{*} & s_{22}
\end{array}\right] C_{t-1}\left[\begin{array}{cc}
s_{11} & s_{12}+s_{12}^{*} \\
s_{21}+c_{21}^{*} & s_{22}
\end{array}\right] \\
& +\left[\begin{array}{cc}
\alpha_{11} & \alpha_{12}+\alpha_{12}^{*} \\
\alpha_{21}+\alpha_{21}^{*} & \alpha_{22}
\end{array}\right]\left[\begin{array}{cc}
k_{1}^{2}, t-1 & k_{2}, t-1 k_{1}, t-1 \\
k_{1}, t-1 k_{2}, t-1 & k_{2}^{2}, t-1
\end{array}\right] \\
& \times\left[\begin{array}{cc}
\alpha_{11} & \alpha_{12}+\alpha_{12}^{*} \\
\alpha_{21}+\alpha_{21}^{*} & \alpha_{22}
\end{array}\right]
\end{aligned}
$$

Equation (3) models the dynamic process $C_{t}$ as a linear function of its own past value $C_{t-1}$ and past value of the squared $\left(k_{1}^{2}, t-1, k_{2}^{2}, t-1\right)$. The GARCH $(1,1)-B E K K$ model proposed by Engle and Kroner [32] ensures that that the covariance matrix in the system is positive definite. Given a sample of $N$ observations, a vector of unknown parameters $\phi$ and a $2 \times 1$ vector of variables $x_{t}$, the conditional density function for model 1 is:

$$
f\left(p_{t} / l_{t-1} ; \phi\right)=(2 \pi)^{-1} / C_{t} /^{-1 / 2} \exp \left(\frac{v_{t}\left(C_{t}^{-1}\right) v_{t}}{2}\right)
$$

The log likelihood function for Equation (4) is as follows:

$$
L=\sum_{t=1}^{T} \log f\left(p_{t} / l_{t-1} ; \phi\right)
$$

where $\phi$ is a vector of unknown parameters. The standard errors are calculated using the quasi-maximum likelihood method proposed by Bollerslev and Wooldridge [33].

When considering the effect of bank capitalisation on stock market liquidity 
(turnover mean equation) we observe significant spillover effect. On the contrary, the effect of stock market liquidity on bank capitalisation is not statistically significant $\left(\beta_{12}=0\right)$.

Concerning the effect of stock market turnover volatility on bank capitalisation volatility, we also find evidence of significant spillovers but there is no evidence of spillovers running from bank capitalisation volatility to stock market turnover volatility.

As for the control variables, the US economy appears to have a leading role with positive and statistically significant coefficients (measured by $\delta_{22}$ ). Furthermore, the US stock market also has a positive impact (measured by $\delta_{11}$ ) on the Nigeria stock market with the estimated coefficients being equal to 0.643 .

Finally, the monetary policy variable found to be significant and indicates that a negative interest rate impact on both stock market growth $\left(\gamma_{11}<0\right)$ and bank capitalisation $\left(\gamma_{22}<0\right)$.

\section{Summary of Findings}

This paper investigates the relationship between stock market liquidity and bank capitalisation in Nigeria using a VAR-GARCH $(1,1)$ framework. The main findings of the study are that bank capitalisation leads to better performing stock market and that the positive impact of bank capitalisation on stock market performance is more noticeable in the long run.

This study's finding has its underpinning on a number of economic theories. The first is the theory of bank capital. One strand in this theory, presented by Diamond and Dybvig [34] and Repullo [35] is of the view that higher bank capital improves liquidity creation by helping banks to absorb risks and expand their risk bearing capacity. These research findings are in line with this argument. It, however, counters the second strand led by Diamond and Rajan [36] which is of the view that greater capital reduces liquidity creation by banks because bank capital reduces financial fragility that facilitates liquidity creation, but enables banks to avoid distress and survive more often.

Another theoretical underpinning for the findings is the financial fragility and risk absorption hypothesis by Berger and Bouwman [30]. One strand in the risk absorption hypothesis is of the view that higher capital enhances the ability of the banks to create liquidity. The findings of our study are that bank capitalisation enables banks to give more loans to the public and this increase in lending has a positive impact on stock market liquidity growth. The research findings also contradict the financial fragility crowding out view that higher capital crowds out liquidity creation by crowding out deposits, but banks with fragile capital receive more deposits and create more liquidity.

Future studies can build a more comprehensive database by including macroeconomic stability variables such as, political risk, bureaucratic accountability, democratic quality, corruption, law and order, shareholders' rights, hydrocarbon and remittances. The data for these variables were available in Nigeria's database 
for only ten years out of the thirty-four years covered in the study.

\section{References}

[1] Abiodun, N.L. and Okunola, O.E. (2012) Stock Prices, Stock Market Operations and Nigeria's Economic Growth: A Granger Causality Modelling. Global Advanced Research Journal of Management and Business Studies, 1, 375-383.

[2] Al-Faki, M. (2006) Capital Market Reforms and Real Sector Financing: What Options.

http://www.sec.gov.ng/uploads/speeches/20090408541420 capital market reforms and real sector financial. pdf

[3] Sullivan, A. and Sheffrin, S.M. (2003) Economics: Principles in Action. Pearson Prentice Hall, Upper Saddle River.

[4] The Nigeria Stock Exchange Fact Book (2012) http://www.nse.com.ng/market-data

[5] Usman, O.A. (2011) The Role of Capital Market on Economic Growth in Nigeria (1980-2008). Research Journal of Finance and Accounting, 2, 201-234.

[6] Nwude C.C. (2012) The Push and Pull Factors of the Capital Market in a Developing Economy. Journal of Accounting and Taxation, 4, 7-18.

[7] Kolapo, F.T. and Adaramola, A.O. (2012) The Impact of the Nigerian Capital Market on Economic Growth (1990-2010). International Journal of Development Societies, 1, 11-19.

[8] Allen, F. and Gale, D. (1997) Financial Markets, Intermediaries and Inter-Temporal Smoothing. Journal of Political Economy, 105, 523-546. https://doi.org/10.1086/262081

[9] Booth, A. and Thakor, A. (1997) Financial System Architecture. Review of Financial Studies, 10, 693-733. https://doi.org/10.1093/rfs/10.3.693

[10] Song, F. and Thakor, A. (2010) Financial System Architecture and the Co-Evolution of Banks and Capital Markets. Economic Journal, 120, 1021-1055. https://doi.org/10.1111/j.1468-0297.2009.02345.x

[11] Clementina, K. and Isu, H.O. (2013) The Impact of Recapitalization on Bank Performance in Nigeria, 1970-2010. International Journal of Business and Management Invention, 2, 12-20.

[12] Gurley, J. and Shaw, E. (1967) Financial Structure and Economic Development. Economic Development and Culture Change, 15, 257-268. https://doi.org/10.1086/450226

[13] Goldsmith, R.W. (1969) Financial Structure and Development. Yale, New Haven.

[14] McKinnon, R.I. (1973) Money and Capital in Economic Development. Brookings Institution, Washington DC.

[15] Shaw, E.S. (1973) Financial Deepening in Economic Development. Oxford University Press, New York.

[16] Caporale, G.M., Hwells, P.G. and Soliman, A.M. (2005) Endogenous Growth Models and Stock Market Development: Evidence from Four Countries. Review of Development Economics, 9, 166-176. https://doi.org/10.1111/j.1467-9361.2005.00270.x

[17] Caporale, G.M., Hwells, P.G. and Soliman, A.M. (2004) Stock Market Development and Economic Growth: The Causal Linkage. Journal of Economic Development, 29, 33-50.

[18] Callderon-Rossell, J.R. (1991) The Determinants of Stock Market Growth, a Worldwide Perspective. Pacific-Basin Capital Markets Research, 11, 523-547. 
[19] Demirguc-Kunt, A. and Levine, R. (1999) Stock Market Development and Financial Intermediaries. Stylized Facts. World Bank Economic Review, 10, 291-321. https://doi.org/10.1093/wber/10.2.291

[20] La Porta, R., deSilanes, F.L., Shleifer, A. and Vishny, R.W. (1996) Legal Determinants of External Finance. Journal of Finance, 52, 1131-1150. https://doi.org/10.1111/j.1540-6261.1997.tb02727.x

[21] Garcia, V.F. and Liu, L. (1999) Macroeconomic Determinants of Stock Market Development. Journal of Applied Economics, 4, 29-59.

[22] Yartey, C.A. (2008) Well-Developed Financial Intermediary Sector Promotes Stock Market Development. Evidence from Africa. Journal of Emerging Markets Finance, 6, 269-289.

[23] Billmeier, A. and Massa, I. (2007) What Drives Stock Market Development in the Middle East and Central Asia Institutions, Remittances or Natural Resources? IMF Working Paper WP/07/157.

[24] Sachs, J. and Warner, A. (1999) The Big Rush, Natural Resources Boom and Growth. Journal of Development Economics, 59, 43-76.

[25] Kemobi, J.K. and Tarus, A.K. (2012) Macroeconomic Determinants of Stock Market Development in Emerging Markets: Evidence from Kenya. Research Journal of Finance and Accounting, 3, 57-68.

Cherif, M. and Gazder, K. (2010) Macroeconomic and Institutional Determinants of Stock Market Development in MENA Region. New Results from Panel Data Analysis. International Journal of Banking and Finance, 7, 139-159.

[26] Idowu, A. and Babatunde, M.A. (2012) Effect of Financial Reforms on Capital Market Development in Nigeria. Asian Journal of Business and Management Sciences, 8, 44-52.

[27] Al-Mamnu, M. (2013) The Effects of Macroeconomic and Market Specific Dynamics on Stock Market Development in Global Growth Generation Countries (3G). Asian Economic and Financial Review, 3, 1152-1169.

[28] Ita, J.J. and Duke, J. (2013) Macroeconomic Factors That Influence Stock Market Development in Nigeria. International Journal of Business Management and Review, 1, 43-56.

[29] El-Nader, M.H. and Alraimony, A.D. (2013) The Macroeconomic Determinants of Stock Market Development in Jordan. International Journal of Economics and Finance, 5, 1123-1144. https://doi.org/10.5539/ijef.v5n6p91

[30] Berger, A.N. and Bouwman, C.H.S. (2009) Bank Liquidity Creation, Monetary Policy and Financial Crises. http://fic.wharton.upenn.edu/fic/papers/09/0923.pdf

Bollerslev, T.P. and Wooldridge, J.M. (1992) Quasi-Maximum Likelihood Estimation and Inference in Dynamic Models with Time-Varying Covariance. Econometric Reviews, 11, 143-172.

[31] Stock, J.H. (1994) Unit Roots and Trend Breaks in Econometrics. In: Engle, R.F. and McFadden, D., Eds., Handbook of Econometrics, 4th Edition, North Holland, New York, 2740-2841.

[32] Engle, R.F. and Kroner, K.F. (1995) Multivariate Simultaneous Generalised ARCH. Econometric Theory, 11, 122-150. https://doi.org/10.1017/S0266466600009063

[33] Bollerslev, T. and Wooldridge, J.M. (1992) Quasi-Maximum Likelihood Estimation and Inference in Dynamic Models with Time Varying Covariances. Econometric Reviews, 11, 143-172. https://doi.org/10.1080/07474939208800229

[34] Diamond, D. and Dybvig, P.H. (1983) Bank Runs, Deposit Insurance and Liquidity. 
Journal of Political Economy, 91, 401-419. https://doi.org/10.1086/261155

[35] Repullo, R. (2004) Capital Requirement, Market Power and Risk Taking in Banking. Journal of Financial Intermediation, 13, 170-193.

[36] Diamond, D.W. and Rajan, R.G. (2001) Liquidity Risk, Liquidity Creation and Financial Fragility: A Theory of Banking. Journal of Political Economy, 109, 267-327. https://doi.org/10.1086/319552

[37] Ljung, G.M. and Box, G.E.P. (1978) On a Measure of Lack of Fit in Tome Series Models. Biometrika, 65, 297-303. https://doi.org/10.1093/biomet/65.2.297 